Brit. J. vener. Dis. (1960), 36, 140.

\title{
THE CAMPAIGN AGAINST SYPHILIS IN HUNGARY*
}

\author{
BY \\ F. FÖLDVÁRI† AND ST. KAROLYI \\ Budapest, Hungary
}

The campaign against venereal disease in Hungary started during World War I, under the direction of Prof. Nékám. The development and organization of this campaign was given greater impetus by the lex veneris in 1940. During World War II the venereal disease centres stopped work and, in the course of reorganization, we not only restored the former facilities, but succeeded in establishing a country-wide service: an increase from 44 to 128 venereal disease dispensaries. This relatively high number-compared with the country's populationis required because these establishments cater for patients with both venereal and skin diseases.

The incidence of venereal diseases reached a peak all over the world after World War II. In a relatively short time thereafter the number of cases decreased for some years but later the decrease stopped, and in some places the incidence rose again. In Hungary - apart from a small increase in 1958-the incidence of early syphilis has decreased steadily (Table I). This consistent decrease, which is more than would be expected from the usual spontaneous fluctuations, seems to be due to our preventive work: to thorough contact-tracing, to hospitalization of early infectious cases, and to intensive penicillin treatment.

TABLE I

TOTAL INCIDENCE OF PRIMARY AND SECONDARY SYPHILIS, 1947-59

\begin{tabular}{c|c}
\hline Year & Number of Cases \\
\hline 1947 & 15,061 \\
1948 & 9,851 \\
1949 & 4,477 \\
1950 & 4,428 \\
1951 & 1,708 \\
1952 & 1,085 \\
1954 & 426 \\
1955 & 126 \\
1956 & 58 \\
1957 & 37 \\
1958 & 18 \\
1959 & 46 \\
9 months) & 5 \\
\hline
\end{tabular}

* Paper read at General Assembly of I.U.V.D.T., London, October 17, 1959.

†Prof. F. Földvári, Budapest VIII, Maria Utca 41, Hungary.
A similar decrease has occurred in the incidence of congenital syphilis. Co-operation between the venereal disease and antenatal clinics ensures early diagnosis in pregnant women and, when necessary, intensive treatment. One could almost say that the rate of decrease in congenital syphilis has kept pace with that observed in early acquired syphilis.

The relevant numerical data, which are available only from 1952, when the clinics all over the country were first required to keep these records, are given in Tables II and III, which include new cases treated since 1952 as well as those in which treatment had been started before 1952 .

TABLE II

EARLY CONGENITAL SYPHILIS, BY AGE OF PATIENT 1952-58

\begin{tabular}{c|c|c}
\hline \multirow{2}{*}{ Year } & \multicolumn{2}{|c}{ Age (yrs) } \\
\cline { 2 - 3 } & Under 1 & 1 to 2 \\
\hline 1952 & 51 & 80 \\
1953 & 14 & 55 \\
1954 & 8 & 34 \\
1955 & 4 & 15 \\
1956 & 3 & 6 \\
1957 & 3 & 3 \\
1958 & 3 & 2 \\
\hline
\end{tabular}

TABLE III

LATE CONGENITAL SYPHILIS, BY AGE OF PATIENT, $1952-58$

\begin{tabular}{c|c|c}
\hline & \multicolumn{2}{|c}{ Age (yrs) } \\
\cline { 2 - 3 } Year & 3 to 4 & 5 and over \\
\hline 1952 & 126 & 1,262 \\
1953 & 79 & 1,295 \\
1954 & 51 & 1,113 \\
1955 & 42 & 1,085 \\
1956 & 18 & 897 \\
1957 & 14 & 789 \\
1958 & 8 & 731 \\
\hline
\end{tabular}

Table II shows the patients who were diagnosed and treated as cases of early symptomatic congenital syphilis up to the age of 1 to 2 years, and Table III shows the older patients with congenital syphilis. Most of those over 5 years of age were actually more than 12 years old, and in these patients the characteristic late signs were seldom seen. These patients were nearly all found by serological screening and the examination of family contacts. 
Table IV shows the total number of patients treated for all stages of syphilis since 1952 throughout the whole country.

TABLE IV

TOTAL INCIDENCE OF ALL STAGES OF SYPHILIS

\begin{tabular}{c|c}
\hline Year & Number of Cases \\
\hline 1952 & 26.611 \\
1953 & 24.652 \\
1954 & 19.141 \\
1955 & 15.571 \\
1956 & 11.468 \\
1957 & 9.936 \\
1958 & 7.707 \\
\hline
\end{tabular}

Table $\mathrm{V}$ shows the percentage distribution of various clinical stages of syphilis.

TABLE V

PERCENTAGE DISTRIBUTION OF STAGES OF SYPHILIS,

\begin{tabular}{c|c|c|c|c}
\multicolumn{1}{|c|}{$1952-58$} \\
Year & $\begin{array}{c}\text { Early and } \\
\text { Latent Acquired }\end{array}$ & Congenital & $\begin{array}{c}\text { Cardio- } \\
\text { vascular }\end{array}$ & $\begin{array}{c}\text { Neuro- } \\
\text { syphilis }\end{array}$ \\
\hline 1952 & $81 \cdot 0$ & $5 \cdot 5$ & $3 \cdot 0$ & $10 \cdot 5$ \\
1953 & $76 \cdot 8$ & $5 \cdot 8$ & $3 \cdot 5$ & $13 \cdot 9$ \\
1954 & $72 \cdot 3$ & $6 \cdot 3$ & $4 \cdot 4$ & $17 \cdot 0$ \\
1955 & $69 \cdot 9$ & $7 \cdot 4$ & $4 \cdot 6$ & $18 \cdot 1$ \\
1956 & $67 \cdot 6$ & $8 \cdot 2$ & $4 \cdot 3$ & $19 \cdot 9$ \\
1957 & $67 \cdot 1$ & $8 \cdot 2$ & $4 \cdot 2$ & $20 \cdot 5$ \\
1958 & $65 \cdot 9$ & $9 \cdot 5$ & $3 \cdot 8$ & $20 \cdot 8$ \\
\hline
\end{tabular}

The distribution of cases of syphilis according to age (Table VI) shows a striking decrease in the 20 to 40-year age group, indicating the relative success in recent years in the control of new infections.

TABLE VI

PERCENTAGE DISTRIBUTION OF AGE GROUPS OF SYPHILIS PATIENTS, $1952-58$

\begin{tabular}{|c|c|c|c|c|c|c|c|}
\hline \multirow{2}{*}{ Year } & \multicolumn{7}{|c|}{ Age Group (yrs) } \\
\hline & Under 1 & $1-9$ & $10-19$ & $20-29$ & $30-39$ & $40-49$ & Over 50 \\
\hline $\begin{array}{l}1952 \\
1953 \\
1954 \\
1955 \\
1956 \\
1957 \\
1958\end{array}$ & $\begin{array}{l}0.2 \\
0.1 \\
0.04 \\
0.02 \\
0.02 \\
0.03 \\
0.03\end{array}$ & $\begin{array}{l}1.9 \\
2.0 \\
1.8 \\
1.4 \\
1.1 \\
1.0 \\
0.7\end{array}$ & $\begin{array}{l}3 \cdot 1 \\
3 \cdot 2 \\
3 \cdot 4 \\
4 \cdot 3 \\
4 \cdot 4 \\
4 \cdot 8 \\
5 \cdot 5\end{array}$ & $\begin{array}{r}21 \cdot 0 \\
16 \cdot 7 \\
13 \cdot 7 \\
12 \cdot 2 \\
12 \cdot 3 \\
9 \cdot 5 \\
9 \cdot 5\end{array}$ & $\begin{array}{l}27 \cdot 6 \\
27 \cdot 7 \\
26 \cdot 4 \\
26 \cdot 0 \\
25 \cdot 8 \\
24 \cdot 2 \\
20 \cdot 9\end{array}$ & $\begin{array}{l}22 \cdot 8 \\
25 \cdot 0 \\
24 \cdot 8 \\
24 \cdot 9 \\
24 \cdot 9 \\
25 \cdot 5 \\
24 \cdot 7\end{array}$ & $\begin{array}{l}23 \cdot 4 \\
25 \cdot 3 \\
29 \cdot 86 \\
31 \cdot 18 \\
31 \cdot 48 \\
34 \cdot 97 \\
38 \cdot 67\end{array}$ \\
\hline
\end{tabular}

The campaign shows the following important features:

(1) The intensive work of the 128 venereal disease clinics which extend over the whole country and are controlled by a central directorate.

(2) The fundamental importance of contact-tracing. In 195843 of the 46 cases of early syphilis arose from two women, who caused twenty direct and 23 indirect infections. The success in contact-tracing was made possible by the central contact-research institute, which co-ordinates the work of the different clinics. In 195776.5 per cent., and in 195878.25 per cent., of syphilitic contacts were successfully traced.

(3) $4,646,830$ screen tests carried out by a rapid precipitation method in the 7 years, 1952-58. The positivity rate was over 2 per cent. in 1952, but in 1958 this had fallen to 0.87 per cent. The cases with positive screen-tests were re-examined by the classical serological tests and, in some cases, by Nelson's T.P.I. test. Since 1954, 11,000 T.P.I. tests have been carried out in about 8,000 patients, and 25 per cent. of the positive screen tests were found to be non-treponemal reactions.

(4) The use of intensive intermittent penicillin treatment.

Venereal disease control work must not, in our opinion, be relaxed. We can still speak only of the control of syphilis, and the eradication of this disease awaits further scientific progress. Experience has shown that relaxation of control too early may permit syphilitic infections to increase again.

\section{La campagne antisyphilitique en Hongrie Résumé}

La campagne antisyphilitique en Hongrie comprend les traits importants suivants:

(1) Le travail intensif des 128 cliniques antivénériennes, dispersées dans le pays entier et contrôlées par un directorat central.

(2) L'importance fondamentale de dépistage des contacts. En 1958, sur 46 cas de syphilis précoce, 43 d'entre eux purent être attribués à deux femmes, sources de 20 infections directes et de 23 indirectes. Le succès du dépistage fut rendu possible par l'institut central de recherche des contacts, qui coordonne le travail de différentes cliniques. En 1957 on réussit à dépister 76,5\%, et en $195878,25 \%$ des contacts syphilitiques.

(3) En sept années, de 1952 à 1958, on procéda à 4.646.830 tests éliminatoires par la méthode de précipitation rapide. Ces tests furent positifs en $2 \%$ des cas en 1952 , mais ce pourcentage tomba à $0,87 \%$ en 1958 . Les cas aux tests éliminatoires positifs furent re-examinés par des réactions sérologiques classiques et, quelquefois, par le test de Nelson (T.P.I.=test d'immobilisation du tréponème). Depuis 1954, 11.000 de ces tests furent effectués chez environ 8.000 patients, et $25 \%$ des tests éliminatoires positifs s'avérèrent non-tréponémiques.

(4) L'emploi du traitement intermittent et intensif par la pénicilline.

Nous croyons que les efforts pour réprimer les maladies vénériennes ne doivent pas être relâchés. Pour le moment on ne peut parler que de la répression de la syphilis, car son éradication doit attendre des progrès scientifiques ultérieurs. L'expérience montre qu'un relâchement prématuré du contrôle peut permettre une nouvelle augmentation de l'infection syphilitique. 